\title{
Myotome Region
}

National Cancer Institute

\section{Source}

National Cancer Institute. Myotome Region. NCI Thesaurus. Code C34214.

The region of the dermomyotome that will form myoblasts (primordial muscle cells). 